\title{
Burkholderia (formerly Pseudomonas) cepacia porin is an oligomer composed of two component proteins
}

\author{
Naomasa Gotoh, Kenji Nagino,† Koichi Wada, Hideto Tsujimoto and \\ Takeshi Nishino
}

Author for correspondence: Naomasa Gotoh. Tel: +8175 595 4642. Fax: +81 755938070 .

Department of Microbiology, Kyoto Pharmaceutical University, Yamashina, Kyoto 607, Japan

\begin{abstract}
The $81 \mathrm{kDa}$ protein (designated OpcPO) which forms a diffusion pore in the outer membrane of Burkholderia (formerly Pseudomonas) cepacia has a unique characteristic in that when the purified protein is heated it yields a major $36 \mathrm{kDa}$ protein (designated OpcP1) and a minor $27 \mathrm{kDa}$ protein (designated OpcP2). Moreover, incubation of OpcPO in citrate buffer at pH 3.0 produced an unusual dissociation into $72 \mathrm{kDa}$ and $27 \mathrm{kDa}$ proteins. For the characterization of OpcPO and its derivatives, OpcP1 and OpcP2 from purified OpcPO were isolated by preparative SDS-PAGE. Reconstitution of OpcPO using purified preparations of OpCP1 and OpcP2 indicated that these derivatives were not proteolytic fragments of OpcPO. Moreover, immunoblot assays with murine polyclonal antisera specific for OpcP1 and OpcP2 yielded the following results: (i) OpcP1 and OpcP2 are immunologically distinguishable proteins; (ii) the unusual dissociation of OpcPO in citrate buffer at pH 3.0 resulted in the release of OpcP2 from OpcPO, and the resulting $72 \mathrm{kDa}$ protein was probably an oligomer of OpcP1; (iii) purified OpcP1 itself produced two additional $53 \mathrm{kDa}$ and $72 \mathrm{kDa}$ proteins spontaneously following elution from the bottom of the SDS-PAGE gel. From these findings, it was concluded that OpcPO is formed by the non-covalent association of OpcP2 with an oligomer of OpcP1 that has the ability to self-assemble.
\end{abstract}

Keywords: Burkbolderia (Pseudomonas) cepacia, porins, outer membrane protein, self assembly

\section{INTRODUCTION}

Burkbolderia (formerly Pseudomonas) cepacia is recognized as a pathogenic agent in nosocomial infections in immunocompromised patients, and causes pulmonary infections in patients with cystic fibrosis (Philips \& Eykyn, 1971; Ederer \& Matsen, 1972; Gilligan, 1991; Smith et al., 1993). One of the clinically important characteristics of $B$. cepacia is its intrinsic high resistance to structurally unrelated antimicrobial agents and disinfectants (Fass \& Barnishan, 1980; Kropp et al., 1985; Gilligan, 1991). Antimicrobial agents other than those affecting the membrane itself have to pass through the outer membranes of Gram-negative bacteria to reach their targets. Accordingly, the permeability of the outer

† Present address: New Product Development Center, Pfeizer Pharmaceuticals Inc., Taketoyo, Aichi 470-23, Japan. membrane to antimicrobial agents influences their effectiveness (Nikaido \& Vaara, 1985; Nikaido, 1989). The intrinsic resistance of B. cepacia to $\beta$-lactam antibiotics has been demonstrated to be caused by the low permeability of the outer membrane, which is approximately 10 times less permeable than that of Escherichia coli and comparable to that of another highly resistant bacterium, $P$. aeruginosa (Parr et al., 1987). Hydrophilic solutes such as most $\beta$-lactams diffuse via water-filled channels in the outer membrane, called porins (Nakae, 1975, 1976), to reach their targets (Nikaido \& Rosenberg, 1983; Yoshimura \& Nikaido, 1985; Nikaido \& Vaara, 1985; Hancock, 1987). Therefore, the characteristics of the porin pore are significant determinants of susceptibility to $\beta$-lactams (Nikaido, 1989).

Analysis by SDS-PAGE determined that the apparent molecular masses of the major outer membrane proteins of $B$. cepacia cells grown in nutrient broth are $40 \mathrm{kDa}$, 
$36 \mathrm{kDa}, 24.5 \mathrm{kDa}, 17 \mathrm{kDa}$ and $14.5 \mathrm{kDa}$, and of these, the $36 \mathrm{kDa}$ and the $24.5 \mathrm{kDa}$ proteins are heat-modifiable (Anwar et al., 1983). Several proteins of the major outer membrane proteins have recently been characterized as follows: (i) The major outer membrane protein of $81 \mathrm{kDa}$ dissociates into a major $36 \mathrm{kDa}$ protein and a minor $27 \mathrm{kDa}$ protein (probably the same as the above $24.5 \mathrm{kDa}$ protein) by heat solubilization and is able to form a diffusion pore in the black lipid bilayer system (Parr et al., 1987). (ii) The function of the $81 \mathrm{kDa}$ protein was suggested by the finding that high-level $\beta$-lactam resistance was associated with decreased expression of the $36 \mathrm{kDa}$ and the $27 \mathrm{kDa}$ proteins (Aronoff \& Stern, 1988). (iii) The $40 \mathrm{kDa}$ protein $(\mathrm{OpcS})$ allows the penetration of chloramphenicol but not penicillin $\mathrm{G}$ in proteoliposome membranes (Burns \& Clark, 1992). These findings indicate that the $81 \mathrm{kDa}$ and the $40 \mathrm{kDa}$ proteins act as porins in the B. cepacia outer membrane. Investigation of the function and structure of the structurally unique $81 \mathrm{kDa}$ protein as compared with the ordinary porin oligomer in Gram-negative bacteria (Nikaido \& Vaara, 1985; Nakae, 1986; Benz, 1988; Nikaido \& Red, 1990; Rosenbusch, 1990) might be useful not only for a general understanding of the drug resistance of B. cepacia, but also for understanding how porins assemble. Despite little information regarding the relationship between the $36 \mathrm{kDa}$ and the $27 \mathrm{kDa}$ proteins, they seem to have been recently accepted as independent components (Aronoff, 1988) or subunits (Burns \& Clark, 1992) from which the $81 \mathrm{kDa}$ protein is constructed.

In this paper we found by observation of the dissociation of the $81 \mathrm{kDa}$ protein and reassociation of its dissociated proteins, and by immunoblots with murine antiserum specific to each of the two dissociated proteins, that the $81 \mathrm{kDa}$ protein is a hetero-oligomer composed of two immunologically distinct component proteins. Moreover, we propose new designations for these porin proteins.

\section{METHODS}

Purification of OpcPo. Parr et al. (1987) purified the $81 \mathrm{kDa}$ porin oligomer (OpcPO) by gel filtration of proteins obtained from residues following SDS extraction of the outer membranes isolated by sucrose density gradient fractionation of $B$. cepacia whole cell lysates. This suggested that OpcPO is a peptidoglycan-associated protein. Therefore, to improve recovery, we used total membranes (cell envelopes) as our starting material instead of outer membranes, and further, used lithium dodecylsulfate (LDS) instead of SDS to prevent crystallization during chromatography.

Briefly, cells grown in $L$ broth consisting of $1 \%(\mathrm{w} / \mathrm{v})$ tryptone (Difco), $0.5 \%(\mathrm{w} / \mathrm{v})$ yeast extract (Difco) and $0.5 \%(\mathrm{w} / \mathrm{v}) \mathrm{NaCl}$ were harvested by centrifugation at $10000 \mathrm{~g}$ for $30 \mathrm{~min}$ at $4{ }^{\circ} \mathrm{C}$. The cells were resuspended in $10 \mathrm{mM}$ Tris/ $\mathrm{HCl}, \mathrm{pH} 8.0$, containing $0.1 \mathrm{mg}$ each of DNase and RNase $\mathrm{ml}^{-1}$, and were passed twice through a French pressure cell at 12000 p.f.i. After removing unbroken cells by centrifugation, total membranes were pelleted from the resulting supernatant by centrifugation at $200000 \mathrm{~g}$ for $1 \mathrm{~h}$. Almost all the membrane proteins in the pellet were removed by extracting twice with $10 \mathrm{mM}$ Tris $/ \mathrm{HCl}$, $\mathrm{pH} 8.0$, containing $2 \%(\mathrm{w} / \mathrm{v})$ LDS followed by centrifugation at $200000 \mathrm{~g}$ for $1 \mathrm{~h}$. Pelleted LDS-insoluble materials (crude peptidoglycan) were suspended in a small volume of $10 \mathrm{mM}$ Tris/ $\mathrm{HCl}, \mathrm{pH} 8.0$, containing $2 \% \mathrm{LDS}$ and $0.5 \mathrm{M} \mathrm{LiCl}$ (Buffer A), and incubated at $37^{\circ} \mathrm{C}$ for $1 \mathrm{~h}$. This suspension was then centrifuged at $200000 \mathrm{~g}$ for $1 \mathrm{~h}$ at $37^{\circ} \mathrm{C}$ and the supernatant was loaded onto a Sephacryl S-200 superfine gel (Pharmacia) column $(2.4 \times 90 \mathrm{~cm})$ equilibrated with Buffer $\mathrm{A}$ and eluted with the same buffer. To remove $\mathrm{LDS}$ and $\mathrm{LiCl}$, OpcPO-rich peaks were pooled and dialysed in $10 \mathrm{mM}$ Tris $/ \mathrm{HCl}, \mathrm{pH} 8.0$, for $2 \mathrm{~d}$. Next, a non-ionic detergent, $2 \%(\mathrm{w} / \mathrm{v})$ nonanoyl- $N$-methylglucamide (MEGA-9; Dojindo), was substituted for the LDS by gel filtration using a Sephadex G-25 gel (Pharmacia) column equilibrated with Buffer B consisting of $2 \%$ (w/v) MEGA-9 in $50 \mathrm{mM}$ sodium phosphate buffer, $\mathrm{pH} \mathrm{7 \cdot 5}$. The OpcPO preparation was then loaded onto a Buffer B-equilibrated TSKgel CM-5PW column $(0.75 \times 7.5 \mathrm{~cm}$; Tosoh) on a high performance liquid chromatograph and was fractionated by elution with a $0-0.5 \mathrm{M}$ linear gradient of $\mathrm{NaCl}$ in Buffer $\mathrm{B}$.

Gel purification of OpcP1 and OpcP2. Purification of OpcP1 and $\mathrm{OpcP} 2$ was performed with a preparative continuouselution SDS-PAGE apparatus (Prep Cell Model 491; Bio-Rad) using the discontinuous buffer system reported by Laemmli (1970). Briefly, a preparation of the purified OpcPO was mixed with 5 vols $6 \mathrm{M}$ guanidine hydrochloride solution. After incubation for $3 \mathrm{~h}$ at $37^{\circ} \mathrm{C}$, guanidine hydrochloride was removed by dialysis against pure water. The dialysed sample was mixed with the same volume of the SDS sample buffer (Hancock \& Carey, 1979) consisting of $1 \mathrm{M}$ Tris/HCl, $\mathrm{pH} \mathrm{6.8,}$ $4 \% \quad(\mathrm{w} / \mathrm{v}) \quad \mathrm{SDS}, 20 \%(\mathrm{v} / \mathrm{v})$ glycerol, $10 \%$ (v/v) 2mercaptoethanol and $0.05 \%$ bromophenol blue, and applied to a stacking gel of $4 \% \mathrm{~T}, 2.67 \% \mathrm{C}$ in the Prep Cell. Proteins which migrated off the bottom of the separating gel of $10 \% \mathrm{~T}$, $2.67 \% \mathrm{C}$ were collected from the flow of Buffer $\mathrm{B}$ and observed by an analytical SDS-PAGE.

Production of respective antisera. $\mathrm{BALB} / \mathrm{c}$ female mice were immunized with $20 \mu \mathrm{g}$ purified OpcP1 or OpcP2 on days 1, 7, 14 and 17. The first injected protein was in Freund's complete adjuvant (Difco), the second and the third were in Freund's incomplete adjuvant (Difco), and the fourth was in PBS. The first, the second and the third were administered intraperitoneally, and the fourth was injected intravenously. Antibody titres in the respective sera were measured by ELISA using crude outer membranes released from briefly sonicated $B$. cepacia as the antigen and peroxidase-conjugated antimouse immunoglobulins (IgG, IgM, IgA) goat IgG (Cappel) as the secondary antibodies according to the method of Harlow \& Lane (1988). Antibody binding was detected using a peroxidase substrate kit (ABTS, Bio-Rad) and colour development was measured at $415 \mathrm{~nm}$ with a microplate reader.

Western immunoblot analysis. Proteins fractionated by SDSPAGE were electrophoretically transferred to nitrocellulose paper $(0.45 \mu \mathrm{m}$ pore size; Bio-Rad) as described by Towbin $e t a l$. (1979). After blocking with PBS, pH 7•4, containing $5 \%(\mathrm{w} / \mathrm{v})$ non-fat dry milk and $0.2 \%$ Tween 20 , the blots were incubated at $37^{\circ} \mathrm{C}$ for $1 \mathrm{~h}$ with the above described peroxidase-conjugated IgG. Peroxidase activity was visualized with a Horseradish Peroxidase Substrate Kit (Bio-Rad).

SDSPAGE and molecular mass determination. Analytical SDS-PAGE was performed using the discontinuous buffer system described by Laemmli (1970) with a $10 \%$ T, $2.60 \% \mathrm{C}$ separating gel. Samples for SDS-PAGE were diluted with an equal volume of SDS sample buffer, and protein bands were visualized by staining with Coomassie brilliant blue. The migration distance of individual proteins following SDS-PAGE 
was determined by densitometry with an LKB Ultroscan XL, and molecular masses were estimated from a linear plot of $\log$ (mass) of standard markers versus their migration distances. Rabbit skeletal muscle myosin $(200000 \mathrm{Da}), E$. coli $\beta$ galactosidase $(116250 \mathrm{Da})$, rabbit muscle phosphorylase $b$ (97400 Da), bovine serum albumin (66200 Da), hen egg white ovalbumin $(45000 \mathrm{Da})$, bovine carbonic anhydrase $(31000 \mathrm{Da})$, soy bean trypsin inhibitor $(21500 \mathrm{Da})$, and hen egg white lysozyme $(14400 \mathrm{Da})$ were used as standard markers.

Determination of protein. Protein was quantified by the Lowry method.

Purification of OmpF. Purification of the OmpF oligomer from E. coli $\mathrm{B}$ was carried out by the method described by Tokunaga et al. (1979).

\section{RESULTS}

\section{Purification of OpcPO, OpcP1 and OpcP2}

For the characterization of $B$. cepacia porin, the $81 \mathrm{kDa}$ porin oligomer was purified from cells of strain ATCC 25416. Most proteins of the total membrane fraction (cell envelope) were solubilized by LDS (Fig. 1, lane 1). Incubation of the insoluble residues in the buffer containing $\mathrm{LDS}$ and $\mathrm{LiCl}$ released several protein species in the size range $81 \mathrm{kDa}$ to $140 \mathrm{kDa}$ (Fig. 1, lane 2). Heating of these proteins to $100{ }^{\circ} \mathrm{C}$ caused the appearance of two proteins with molecular masses $36 \mathrm{kDa}$ and $27 \mathrm{kDa}$, respectively, and the disappearance of all $81 \mathrm{kDa}-110 \mathrm{kDa}$

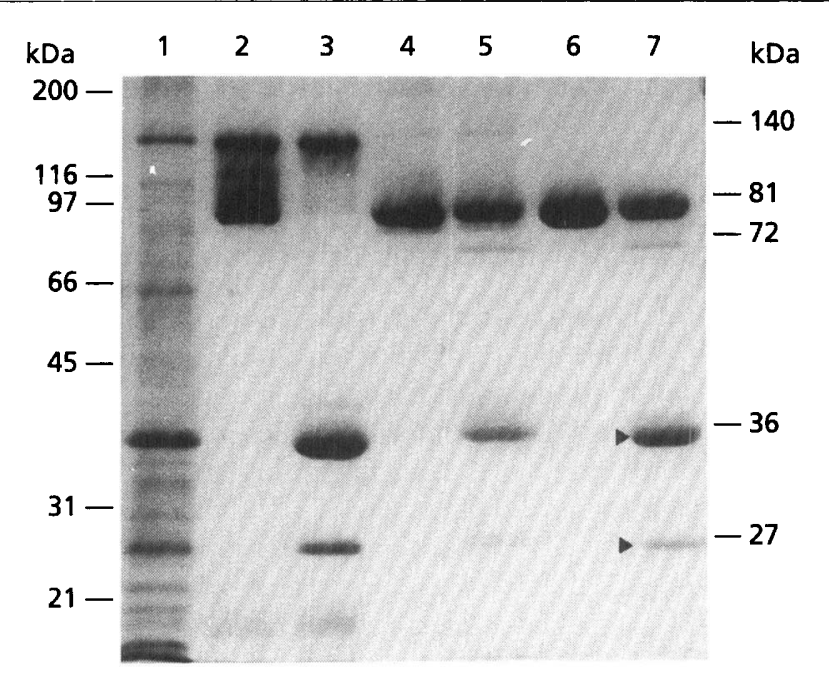

Fig. 1. Purification of the $81 \mathrm{kDa}$ protein. Cell envelope proteins from B. cepacia ATCC 25416 were fractionated as described in Methods. Samples were solubilized at $25^{\circ} \mathrm{C}$ for $10 \mathrm{~min}$ (lanes 2,4 and 6) or at $100^{\circ} \mathrm{C}$ for $10 \mathrm{~min}$ (lanes $1,3,5$ and 7) and subjected to SDS-PAGE. Lanes: 1, LDS extracts (20 $\mu \mathrm{g}$ protein) from envelopes; 2 and 3 , proteins released from crude peptidoglycan (15 $\mu \mathrm{g}$ protein); 4 and 5 , an OpcPO-rich fraction $(7 \mu \mathrm{g}$ protein) after fractionation by gel filtration chromatography with Sephacryl S-200; 6 and 7, an OpcPO fraction $(7 \mu \mathrm{g}$ protein) after ion-exchange chromatography with TSKgel CM-5PW. Arrowheads show the $36 \mathrm{kDa}$ (OpCP1) and the $27 \mathrm{kDa}$ (OpcP2) proteins dissociated from the purified $81 \mathrm{kDa}$ protein. The mobilities of standard proteins and apparent molecular masses of relevant protein bands are shown on the left and the right of the gel, respectively. proteins, although a major $140 \mathrm{kDa}$ protein remained (Fig. 1, lane 3). Although the $36 \mathrm{kDa}$ and the $27 \mathrm{kDa}$ proteins were suspected to be derived from the $81 \mathrm{kDa}$ protein reported by Parr $e t$ al. (1987), we were surprised that no $81 \mathrm{kDa}$ protein band was observed in the heated protein preparation released from the crude peptidoglycan (Fig. 1, lane 3). To positively identify the origin of the $36 \mathrm{kDa}$ and the $27 \mathrm{kDa}$ proteins, we fractionated the peptidoglycan-associated proteins by gel filtration chromatography. SDS-PAGE of the pooled fractions showed an $81 \mathrm{kDa}$ protein (Fig. 1, lane 4) which dissociated into a major $36 \mathrm{kDa}$ protein and minor $27 \mathrm{kDa}$ and $72 \mathrm{kDa}$ proteins after heating at $100^{\circ} \mathrm{C}$ (Fig. 1, lane 5). Isolation of the single $81 \mathrm{kDa}$ protein was accompanied by the disappearance of the $140 \mathrm{kDa}$ protein, suggesting that the $81 \mathrm{kDa}$ protein was derived from the $140 \mathrm{kDa}$ protein during the gel filtration chromatography.

High-performance cation exchange chromatography of the gel filtration product supplied a preparation of more than $98 \%$ pure $81 \mathrm{kDa}$ protein, as determined by densitometry of Coomassie brilliant blue-stained gels (Fig. 1, lane 6). Dissociation of this $81 \mathrm{kDa}$ protein by heating to $100{ }^{\circ} \mathrm{C}$ generated bands of molecular mass $72 \mathrm{kDa}, 36 \mathrm{kDa}$ and $27 \mathrm{kDa}$, although most of the $81 \mathrm{kDa}$ protein remained undissociated (Fig. 1, lane 7). The lack of the $72 \mathrm{kDa}$ band prior to heating (Fig. 1, lane 6) suggested that this band was derived from dissociation of the $81 \mathrm{kDa}$ protein. Dissociation of our purified $81 \mathrm{kDa}$ protein into $36 \mathrm{kDa}$ and $27 \mathrm{kDa}$ species demonstrated that this $81 \mathrm{kDa}$ protein is the major porin oligomer of $B$. cepacia identified by Parr et al. (1987) and confirmed by Aronoff (1988) and Burns \& Clark (1992). No further dissociation of the oligomer into the two proteins was achieved by prolonged heating (data not shown). These results suggest that this $81 \mathrm{kDa}$ oligomeric protein exists as a tight complex. Burns \& Clark (1992) previously designated the $36 \mathrm{kDa}$ protein as OpcP. To represent the relationship between the $81 \mathrm{kDa}$ porin oligomer and its component proteins, we designated the $81 \mathrm{kDa}$ B. cepacia porin oligomer, the $36 \mathrm{kDa}$ protein and the $27 \mathrm{kDa}$ protein as OpcPO, OpcP1 and OpcP2, respectively.

Guanidine hydrochloride or urea caused OpcPO to dissociate into OpcP1 and OpcP2 at temperatures lower than $100^{\circ} \mathrm{C}$. Partial dissociation of OpcPO into OpcP1 and $\mathrm{OpcP} 2$ at $50^{\circ} \mathrm{C}$ in $8 \mathrm{M}$ urea solution (Fig. 2, lane 5) and at $37^{\circ} \mathrm{C}$ in $6 \mathrm{M}$ guanidine hydrochloride solution (Fig. 2, lane 7) was observed. Heating to $70^{\circ} \mathrm{C}$ in either of these solutions caused the complete disappearance of the band representing OpcPO and enlarged both bands representing OpcP1 and OpcP2 (Fig. 2, lanes 6 and 9), whereas OpcPO was scarcely dissociated even at $70^{\circ} \mathrm{C}$ in $1 \mathrm{M} \mathrm{NaCl}$ solution (Fig. 2, lane 3). OpcPO was stable following incubation at $37^{\circ} \mathrm{C}$ and at $50^{\circ} \mathrm{C}$ in guanidine hydrochloride solutions at concentrations less than $5 \mathrm{M}$ and in urea solutions of less than $7 \mathrm{M}$, respectively (data not shown).

Incubation of purified OpcPO in citrate buffer $(\mathrm{pH} 3.0)$ at $50{ }^{\circ} \mathrm{C}$ showed an unusual dissociation into two proteins of $72 \mathrm{kDa}$ and $27 \mathrm{kDa}$ (Fig. 3, lane 3). However, no 


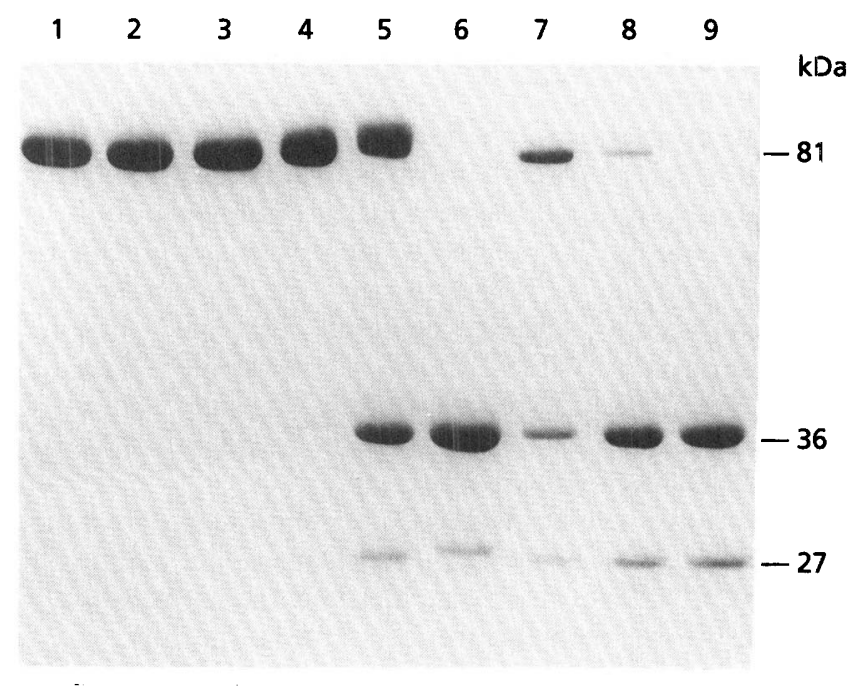

Fig. 2. Dissociation of OpcPO in the presence of sodium chloride, urea and guanidine hydrochloride. The purified OpcPO ( $7 \mu \mathrm{g}$ protein) was diluted with 5 vols $1 \mathrm{M} \mathrm{NaCl}$ (lanes 1, 2 and 3), $8 \mathrm{M}$ urea solution (lanes 4,5 and 6 ) or $6 \mathrm{M}$ guanidine hydrochloride solution (lanes 7, 8 and 9) and these mixtures were then incubated for $30 \mathrm{~min}$ at the following temperatures: lanes 1,4 and $7,37^{\circ} \mathrm{C}$; lanes 2,5 and $8,50^{\circ} \mathrm{C}$; lanes 3,6 and 9 , $70^{\circ} \mathrm{C}$. After removing $\mathrm{NaCl}$, urea and guanidine hydrochloride by dialysis against pure water, samples were solubilized at $25^{\circ} \mathrm{C}$ for $10 \mathrm{~min}$ and subjected to SDS-PAGE. Molecular masses of relevant protein bands are shown on the right of the gel.

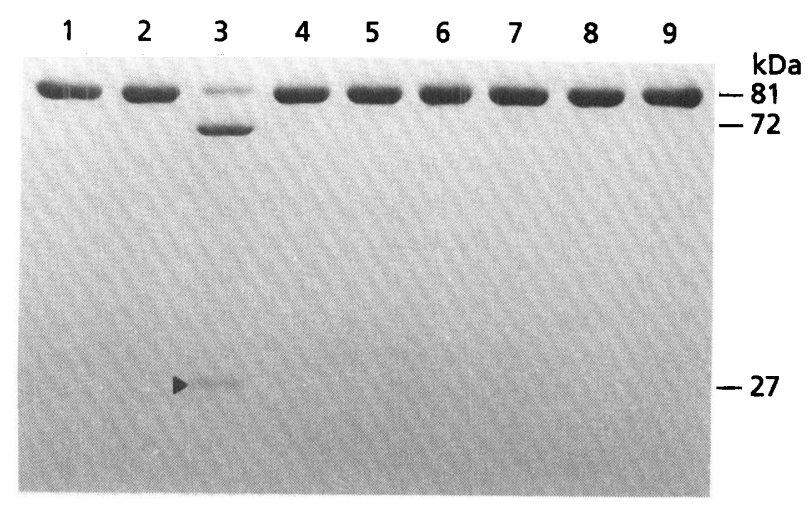

Fig. 3. Dissociation of OpcPO in citrate buffer. Purified OpcPO (7 $\mu \mathrm{g}$ protein) was diluted with 5 vols $100 \mathrm{mM}$ citrate buffer at the following $\mathrm{pH}$ : lanes 1-3, pH 3.0; lanes 4-6, pH 4.0; lanes 7-9, $\mathrm{pH}$ 5.0. The mixtures were then incubated overnight at the following temperatures: lanes 1,4 and $7,20^{\circ} \mathrm{C}$; lanes 2, 5 and $8,37^{\circ} \mathrm{C}$; lanes 3,6 and $9,50^{\circ} \mathrm{C}$. Finally, samples were solubilized at $25^{\circ} \mathrm{C}$ for $10 \mathrm{~min}$ and subjected to SDS-PAGE. The arrowhead shows the $27 \mathrm{kDa}$ protein (OpcP2) released from the $81 \mathrm{kDa}$ protein (OpcPO). Molecular masses of relevant protein bands are shown on the right of the gel.

dissociation of OpcPO was observed in the same buffer at $\mathrm{pH} 4.0$ or $5 \cdot 0$, even when incubated at $50^{\circ} \mathrm{C}$ (Fig. 3, lanes 4-9). To investigate the cause of this unusual dissociation, OpcPO was incubated at $50^{\circ} \mathrm{C}$ in other buffer systems at $\mathrm{pH} 3.0$. In phthalate buffer, OpcPO dissociated completely into OpcP1 and OpcP2 on incubation for $10 \mathrm{~h}$, (a)

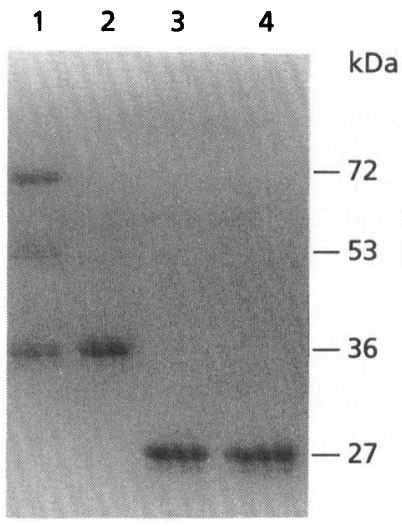

(b)

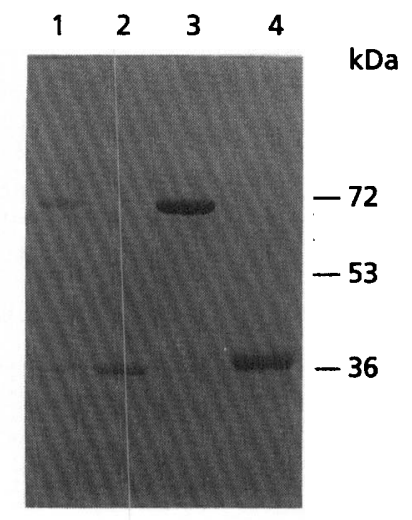

Fig. 4. (a) OpcP1 and OpcP2 purified by the Prep Cell system. OpcP1 and OpcP2 derived from the purified OpcPO in $6 \mathrm{M}$ guanidine hydrochloride were fractionated with the Prep Cell system. Lanes: 1 and 2, purified OpcP1; 3 and 4, purified OpcP2. (b) Comparison of mobilities of OpcP1 and OmpF. OmpF was purified from $E$. coli B cells. Lanes: 1 and 2, purified OpcP1; 3 and 4 , purified $O \mathrm{mpF}$ from $E$. coli B cells. Samples were solubilized at $25^{\circ} \mathrm{C}$ for $10 \mathrm{~min}$ (lanes 1 and 3) or at $100^{\circ} \mathrm{C}$ for 10 min (lanes 2 and 4) and subjected to SDS-PAGE. Molecular masses of relevant protein bands are shown on the right of the gel.

although OpcPO was stable even after incubation for $20 \mathrm{~h}$ in both glycin $/ \mathrm{HCl}$ and acetate buffers (data not shown). Thus, the unusual dissociation of OpcPO into the $72 \mathrm{kDa}$ and $27 \mathrm{kDa}$ proteins is specific for citrate and phthalate buffers at $\mathrm{pH} \mathrm{3.0.} \mathrm{It} \mathrm{is} \mathrm{possible} \mathrm{that} \mathrm{the} \mathrm{weak} \mathrm{divalent-ion}$ chelating abilities of these two buffers may stimulate the dissociation of OpcPO.

\section{Purification and characterization of OpcP1 and OpcP2}

OpcP1 and OpcP2 were independently isolated by the Prep Cell system. The mobility of OpcP2, which eluted earlier than OpcP1 on SDS-PAGE gels, was unaffected by heating (Fig. 4a, lanes 3 and 4). On the other hand, SDSPAGE of the OpcP1 preparation resulted in the following distinguishable profiles: a band of OpcP1 with the addition of two protein bands of higher molecular mass $\left(72 \mathrm{kDa}\right.$ and $53 \mathrm{kDa}$ ) following solubilization at $25^{\circ} \mathrm{C}$ (Fig. 4a, b, lanes 1); and a single $36 \mathrm{kDa}$ band following solubilization at $100{ }^{\circ} \mathrm{C}$ (Fig. $4 \mathrm{a}, \mathrm{b}$, lanes 2$)$. These results indicated that the $72 \mathrm{kDa}$ and the $53 \mathrm{kDa}$ bands observed in the purified OpcP1 preparation were generated by the self-assembly of OpcP1 in buffer containing MEGA-9. Addition of purified OpcP2 into the purified OpcP1 preparation containing the two proteins of higher molecular mass allowed the emergence of the $81 \mathrm{kDa}$ assembly product, presumably representing OpcPO, with accompanying decreases of the $27 \mathrm{kDa}$, the $36 \mathrm{kDa}$ and the $53 \mathrm{kDa}$ proteins. Moreover, the amount of the $81 \mathrm{kDa}$ product increased with the amount of purified OpcP2 added (Fig. 5).

For comparison, the OmpF trimer, which forms the major diffusion pore in the $E$. coli outer membrane 


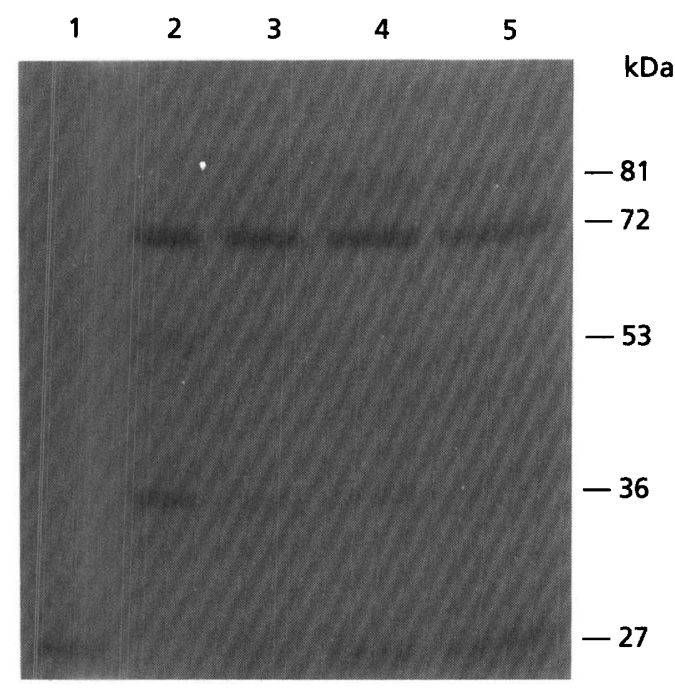

Fig. 5. Formation of a higher molecular mass product by association of OpcP1 and OpcP2. Purified OpcP1 and OpcP2 prepared in $30 \mathrm{mM}$ sodium phosphate buffer, $\mathrm{pH} 7.5$, containing $2 \%$ MEGA-9 were mixed and incubated at $37^{\circ} \mathrm{C}$. After $8 \mathrm{~h}$, the mixtures were solubilized at $25^{\circ} \mathrm{C}$ for $10 \mathrm{~min}$ and subjected to SDS-PAGE. Lanes: 1 , OpcP2 $(2.03 \mu \mathrm{g} ; 75 \mathrm{pmol}$ as molecular mass $27 \mathrm{kDa}) ; 2$, OpcP1 $(3.6 \mu \mathrm{g} ; 100 \mathrm{pmol}$ as molecular mass $36 \mathrm{kDa}) ; 3$, OpcP1 $(4.3 \mu \mathrm{g} ; 120 \mathrm{pmol})$ plus OpcP2 $(1.62 \mu \mathrm{g} ; 60 \mathrm{pmol}) ; 4$, OpcP1 $(4.3 \mu \mathrm{g} ; 120 \mathrm{pmol})$ plus OpcP2 (3.24 $\mu \mathrm{g} ; 120 \mathrm{pmol}) ; 5$, OpcP1 $(4.3 \mu \mathrm{g} ; 120 \mathrm{pmol})$ plus OpcP2 $(3.89 \mu \mathrm{g} ; 144 \mathrm{pmol})$. Molecular masses of relevant protein bands are shown on the right of the gel.

(Steven et al., 1977; Nakae et al., 1979; Kameyama et al., 1982; Maezawa et al., 1983), was purified from E. coli B and its mobilities tested on the same SDS-PAGE gels. The purified $\mathrm{OmpF}$ trimer migrated at the positions corresponding to $72 \mathrm{kDa}$ and $36 \mathrm{kDa}$ after solubilization at $25^{\circ} \mathrm{C}$ and $100{ }^{\circ} \mathrm{C}$, respectively (Fig. 4b, lanes 3 and 4).

\section{Immunological characterization of OpcPO, OpcP1 and OpcP2}

Immunization of mice with either OpcP1 or OpcP2 purified by the Prep Cell system resulted in a strong antibody response, indicating that these proteins are immunogenic in vivo. The dissociated or assembled proteins observed in the above experiments were then characterized by immunoblot assays with each of the polyclonal antisera from the immunized mice.

Antisera from OpcP1- and OpcP2-immunized mice reacted with $\mathrm{OpcP} 1$ and $\mathrm{OpcPO}$, and $\mathrm{OpcP} 2$ and $\mathrm{OpcPO}$, respectively, in the purified OpcPO preparation (Fig. 6, lanes 3 and 4). Reactions of both these antisera with the heated preparation of outer membrane proteins released from briefly sonicated $B$. cepacia cells exhibited a signal corresponding to a $140 \mathrm{kDa}$ protein as well as the respective OpcP2 and OpcP1 protein, but not to OpcPO (Fig. 6, lanes 1 and 2). No cross-reaction of either sera between OpcP1 and OpcP2 was observed in either of these assays (Fig. 6, lanes 1-4).

Further immunoblotting revealed the following. (i) Anti-

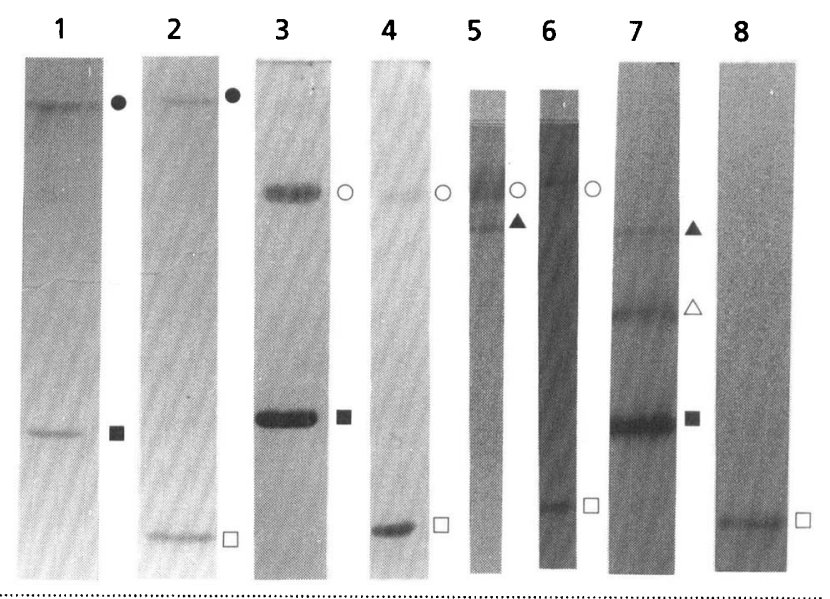

Fig. 6. Identification of dissociated proteins by immunoblot assays. The immunoreactivities of antisera raised against OpcP1 (lanes 1, 3, 5 and 7) and to OpcP2 (lanes 2, 4, 6, and 8) were tested with outer membrane proteins released from briefly sonicated B. cepacia cells (lanes 1 and 2 ), with the purified OpcPO (lanes 3-6), the purified OpcP1 (lane 7) and the purified OpcP2 (lane 8). The antigens were solubilized thus: lanes 1-4, at $100{ }^{\circ} \mathrm{C}$ for $10 \mathrm{~min}$; lanes 5 and 6 , at $25^{\circ} \mathrm{C}$ for $10 \mathrm{~min}$ after overnight incubation at $50^{\circ} \mathrm{C}$ in $100 \mathrm{mM}$ citrate buffer, $\mathrm{pH} 3.0$; lanes 7 and 8 , at $25^{\circ} \mathrm{C}$ for $10 \mathrm{~min}$. After fractionation by SDSPAGE, proteins in the gel were analysed by immunoblot assays with murine polyclonal antisera. The molecular masses of signals are shown by symbols on the right of each lane. $140 \mathrm{kDa}$; $0,81 \mathrm{kDa} ; \triangle, 72 \mathrm{kDa} ; \triangle, 53 \mathrm{kDa} ; \square, 36 \mathrm{kDa}$; $\square$, $27 \mathrm{kDa}$.

serum raised against $\mathrm{OpcP} 1$ recognized the $72 \mathrm{kDa}$ protein, but not the $27 \mathrm{kDa}$ protein that is produced from OpcPO after incubation in citrate buffer at $\mathrm{pH} 3.0$ (Fig. 6 , lane 5). Antiserum against $\mathrm{OpcP} 2$ detected only the $27 \mathrm{kDa}$ protein, but not the $72 \mathrm{kDa}$ protein (Fig. 6, lane 6). (ii) Antiserum specific for OpcP1 reacted with the $72 \mathrm{kDa}$ and the $53 \mathrm{kDa}$ proteins in the preparation of purified OpcP1 (Fig. 6, lane 7), but these proteins were not detected by antiserum raised against OpcP2 (Fig. 6, lane 8). These findings supported the results of the previous dissociation experiment and suggested that OpcP1 has the ability to self-assemble, producing the $72 \mathrm{kDa}$ and the $53 \mathrm{kDa}$ products, and that OpcPO is ultimately produced by the association of a $27 \mathrm{kDa}$ protein, probably OpcP2, with the $72 \mathrm{kDa}$ assembly product.

\section{DISCUSSION}

Porin oligomers from Gram-negative bacteria such as $E$. coli and Salmonella typhimurium dissociate into their respective homologous protein sub-units (Benz, 1988). However, the $81 \mathrm{kDa}$ protein which we have designated OpcPO in the B. cepacia outer membrane dissociates into two proteins with different mobilities on SDS-PAGE gels (Parr et al., 1987). Although this unique heterogeneity of OpcPO has been confirmed by several investigators (Aronoff, 1988; Burns \& Clark, 1992), there is little information on the relationship between these proteins. Prior to investigation of the individual functions of the proteins derived from OpcPO, it is important to resolve 
the following question to determine the basic relationship between these molecules: are OpcP1 and OpcP2 proteolytic fragments of OpcPO accompanying its dissociation, or does OpcPO contain native heterogeneous subunit proteins?

To resolve the above question, we independently purified OpcP1 and OpcP2 from a preparation of OpcPO. Formation of an assembled product, with a molecular mass corresponding to that of OpcPO from a mixture of purified OpcP1 and OpcP2 (Fig. 5) indicated that OpcP1 and $\mathrm{OpcP} 2$ are not proteolytic fragments. The purified proteins were used for the production of murine antisera directed against each to resolve another question: if $\mathrm{OpcP} 2$ is a proteolytic product derived from OpcP1, the antiserum directed against $\mathrm{OpcP} 2$ should also recognize OpcP1 because OpcP1 should contain OpcP2. Immunoblot assays with both murine antisera showed that no cross-reaction between OpcP1 and OpcP2 (Fig. 6) occurred. Furthermore, the heat-dissociation of OpcP1 into its components generated neither a band corresponding to OpcP2 on SDS-PAGE (Fig. 4) nor a signal corresponding to OpcP2 in the immunoblots (Fig. 6). Failure to detect cross-reactivity between antisera to either OpcP1 or OpcP2, and the lack of demonstrable OpcP2 in the heat-treated OpcP1 preparation indicated that OpcP2 is not a proteolytic derivative of $\mathrm{OpcP} 1$, and further that $\mathrm{OpcP1}$ and OpcP2 are immunologically distinguishable component subunits of OpcPO.

Further characteristics of $\mathrm{OpcPO}$ and its subunit proteins were determined as follows. Immunoblot assays (Fig. 6) with antisera directed against either OpcP1 or OpcP2 indicated that incubation of OpcPO in citrate buffer at $\mathrm{pH} 3.0$ brought about its dissociation into a $72 \mathrm{kDa}$ oligomer of $\mathrm{OpcP} 1$, and a $27 \mathrm{kDa}$ protein, identified as OpcP2. Formation of the $72 \mathrm{kDa}$ product from purified $\mathrm{OpcP} 1$ and subsequent heat-dissociation of this $72 \mathrm{kDa}$ product into OpcP1 in the absence of other polypeptides (Fig. 4) supported the conclusion that the $72 \mathrm{kDa}$ protein recovered from citrate buffer at $\mathrm{pH} 3.0$ was an oligomer assembled from OpcP1 alone. The oligomer-forming activity of OpcP1 suggests that OpcPO is itself constructed by a non-covalent association between OpcP2 and the $72 \mathrm{kDa}$ oligomer. The findings presented here indicate that OpcPO is a unique hetero-oligomer composed of two distinguishable subunit proteins in contrast to enteric bacterial porin oligomers, such as $\mathrm{OmpF}$ (Steven et al., 1977; Nakae et al., 1979; Kameyama et al., 1982; Maezawa et al., 1983), OmpC (Palva, 1979) and PhoE (Palva \& Randall, 1978; Yu et al., 1979), which exist as trimers formed from homologous protein subunits.

The existence of two assembly products of molecular mass greater than that of OpcP1 in the purified OpcP1 preparation suggested that dimers and trimers of OpcP1 may form. If this is true, the $72 \mathrm{kDa}$ product would be expected to migrate at a different position corresponding to a molecular mass of $108 \mathrm{kDa}$, which can be calculated for a trimer of the $36 \mathrm{kDa}$ protein, on SDS-PAGE. Similarly a dimer of OpcP1 might be expected to migrate to a position equal to $72 \mathrm{kDa}$. However, there was substantial disagreement between the mobilities seen by SDS-PAGE and the calculated values. To resolve this problem we examined $\mathrm{OmpF}$ from $E$. coli, which exists in a trimeric form with a molecular mass of $108 \mathrm{kDa}$ under normal conditions. Using our separation conditions, the OmpF trimer migrated to a position identical to that of the OpcP1 $72 \mathrm{kDa}$ oligomer on the same gel (Fig. 4b). This suggested that the true molecular mass of the trimer of OpcP1 may be similar to that of OmpF, i.e. $108 \mathrm{kDa}$.

SDS-PAGE of the heat-treated OpcPO preparation (Fig. 1) indicated that the content of OpcP2 in the OpcPO molecule is less than that of OpcP1. Our results suggest that OpcPO is formed from three molecules of OpcP1 and one or two molecule(s) of OpcP2. Detection of a $140 \mathrm{kDa}$ protein in the immunoblots of the preparation of outer membrane proteins released from the $B$. cepacia cells by brief sonication (Fig. 6) indicates that OpcPO is present as a higher molecular mass aggregate in the native outer membrane. This is supported by the observation that the $140 \mathrm{kDa}$ protein, but not the $81 \mathrm{kDa}$ species, occurred in the protein preparation released from crude peptidoglycan, and that this $140 \mathrm{kDa}$ protein could be dissociated into OpcP1 and OpcP2 by heating.

In summary, we have demonstrated that $\mathrm{OpcPO}$, a major porin oligomer from $B$. cepacia, is formed by the noncovalent association of two distinct subunit proteins, $\mathrm{OpcP1}$ and OpcP2.

\section{ACKNOWLEDGEMENTS}

This research was supported by a Grant-in-Aid for Scientific Research from the Ministry of Education, Culture and Science of Japan. We thank Hiroshi Yamada for helpful advice on protein purification and Peter Macklon for assistance in the preparation of the manuscript.

\section{REFERENCES}

Anwar, H., Brown, M. R. W., Cozens, R. M. \& Lambert, P. A. (1983). Isolation and characterization of the outer and cytoplasmic membranes of Pseudomonas cepacia. J Gen Microbiol 129, 499-507.

Aronoff, A. C. (1988). Outer membrane permeability in Pseudomonas cepacia: diminished porin content in a $\beta$-lactam-resistant mutant and in resistant cystic fibrosis isolates. Antimicrob Agents Chemother 32, 1636-1639.

Aronoff, S. C. \& Stern, R. C. (1988). Serum IgG antibody to outer membrane antigens of Pseudomonas cepacia and Pseudomonas aeruginosa in cystic fibrosis. J Infect Dis 157, 934-940.

Benz, R. (1988). Structure and function of porins from Gramnegative bacteria. Annu Rev Microbiol 42, 359-393.

Burns, J. L. \& Clark, D. K. (1992). Salicylate-inducible antibiotic resistance in Pseudomonas cepacia associated with absence of a poreforming outer membrane protein. Antimicrob Agents Chemother 36, 2280-2285.

Ederer, G. M. \& Matsen, J. M. (1972). Colonization and infection with Pseudomonas cepacia. J Infect Dis 125, 613-618.

Fass, R. J. \& Barnishan, J. (1980). In vitro susceptibilities of nonfermentative Gram-negative bacilli other than Pseudomonas aeruginosa to 32 antimicrobial agents. Rev Infect Dis 2, 841-853.

Gilligan, P. H. (1991). Microbiology of airway disease in patients with cystic fibrosis. Clin Microbiol Rev 4, 35-51. 
Hancock, R. E. W. (1987). Role of porins in outer membrane permeability. J Bacteriol 169, 929-933.

Hancock, R. E. W. \& Carey, A. M. (1979). Outer membrane of Pseudomonas aeruginosa: heat- and 2-mercaptoethanol-modifiable proteins. J Bacteriol 140, 902-910.

Harlow, E. \& Lane, D. (1988). Antibodies: A Laboratory Manual. Cold Spring Harbor, New York: Cold Spring Harbor Laboratory.

Kameyama, K., Nakae, T. \& Takagi, T. (1982). Estimation of molecular weight of membrane proteins in the presence of SDS by low-angle laser light scattering combined with high-performance porous silica gel chromatography confirmation of the trimer structure of porin of the Escherichia coli outer membrane. Biochim Biophys Acta 706, 19-26.

Kropp, H., Gerckeus, L., Sundelof, J. G. \& Kahan, F. M. (1985). Antibacterial activity of imipenem: the first thienamycin antibiotic. Rev Infect Dis 7, S389-410.

Laemmli, U. K. (1970). Cleavage of structural proteins during the assembly of the head of bacteriophage T4. Nature 227, 680-685.

Maezawa, S., Hayashi, Y., Nakae, T., Ishii, J., Kameyama, K. \& Takagi, T. (1983). Determination of molecular weight of membrane proteins by the use of low-angle laser light scattering combined with high-performance gel chromatography in the presence of a non-ionic surfactant. Biochim Biophys Acta 747, 291-297.

Nakae, T. (1975). Outer membrane of Salmonella typhimurium: Reconstitution of sucrose-permeable membrane vesicles. Biochem Biophys Res Commun 64, 1224-1230.

Nakae, T. (1976). Outer membrane of Salmonella. Isolation of protein complex that produces transmembrane channels. $J$ Biol Chem 251, 2176-2178.

Nakae, T. (1986). Outer-membrane permeability of bacteria. Crit Rev Microbiol 13, 1-62.

Nakae, T., Ishii, J. \& Tokunaga, M. (1979). Subunit structure of functional porin oligomers that form permeability channels in the outer membrane of Escherichia coli. J Biol Chem 254, 1457-1461.

Nikaido, H. (1989). Outer membrane barrier as a mechanism of antimicrobial resistance. Antimicrob Agents Chemother 33, 1831-1836.

Nikaido, H. \& Red, J. (1990). Biogenesis of prokaryotic pores. Experientia 46, 174-180.
Nikaido, H. \& Rosenberg, E. Y. (1983). Porin channels in Escherichia coli: Studies with liposomes reconstituted from purified proteins. $J$ Bacteriol 153, 241-252.

Nikaido, H. \& Vaara, M. (1985). Molecular basis of bacterial outer membrane permeability. Microbiol Rev 49, 1-32.

Palva, E. T. \& Randall, L. L. (1978). Arrangement of protein I in Escherichia coli outer membrane: Cross-linking study. J Bacteriol 133, 279-286.

Palva, E. T. (1979). Arrangement of protein II, a phage-directed major outer membrane protein in Escherichia coli. FEMS Microbiol Lett 5, 73-76.

Parr, T. R., Moore, R. A., Moore, L. V. \& Hancock, R. E. W. (1987). Role of porins in intrinsic antibiotic resistance of Pseudomonas cepacia. Antimicrob Agents Chemother 31, 121-123.

Philips, I. \& Eykyn, S. (1971). Pseudomonas cepacia (multivorans) septicemia in an intensive care unit. Lancet 1, 375-377.

Rosenbusch, J. P. (1990). Structure and functional properties of porin channels in E. coli outer membranes. Experientia 46, 167-173.

Smith, D. L., Gumery, L. B., Smith, E. G., Stableforth, D. E., Kaufmann, M. E. \& Pitt, T. L. (1993). Epidemic of Pseudomonas cepacia in an adult cystic fibrosis unit: evidence of person-to-person transmission. J Clin Microbiol 31, 3017-3022.

Steven, A. C., ten Heggler, B., Muller, R., Kistler, J. \& Rosenbusch, J. P. (1977). Ultrastructure of a periodic protein layer in the outer membrane of Eschericbia coli. J Cell Biol 72, 292-301.

Tokunaga, M., Tokunaga, H., Okajima, Y. \& Nakae, T. (1979). Characterization of porin from the outer membrane of Salmonella typhimurium 2. Physical properties of the functional oligomeric aggregates. Eur J Biochem 95, 441-448.

Towbin, H., Staehelin, T. \& Gordon, J. (1979). Electrophoretic transfer of proteins from polyacrylamide gels to nitrocellulose sheets. Proc Natl Acad Sci US A 76, 4350-4354.

Yoshimura, F. \& Nikaido, H. (1985). The porin channels of Escherichia coli K-12. Antimicrob Agents Chemother 27, 84-92.

Yu, J., Ichihara, S. \& Mizushima, S. (1979). A major outer membrane protein (O-8) of Escherichia coli $\mathrm{K}-12$ exists as a trimer in sodium dodecylsulfate solution. FEBS Lett 100, 71-74.

Received 2 June 1994; revised 29 July 1994; accepted 11 August 1994. 